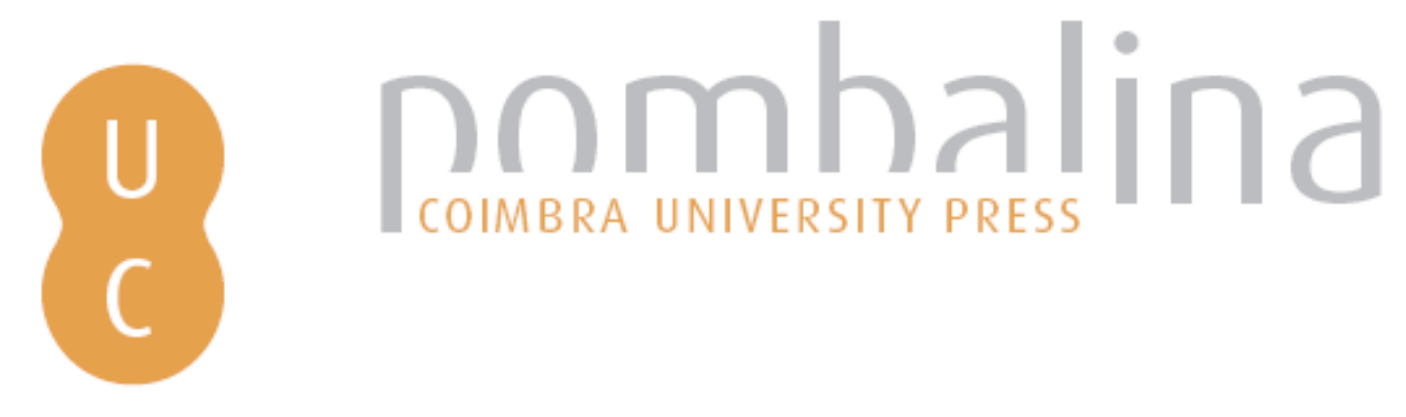

\title{
RPI Engine: visualization in a web environment of post-fire regeneration using Landsat time series
}

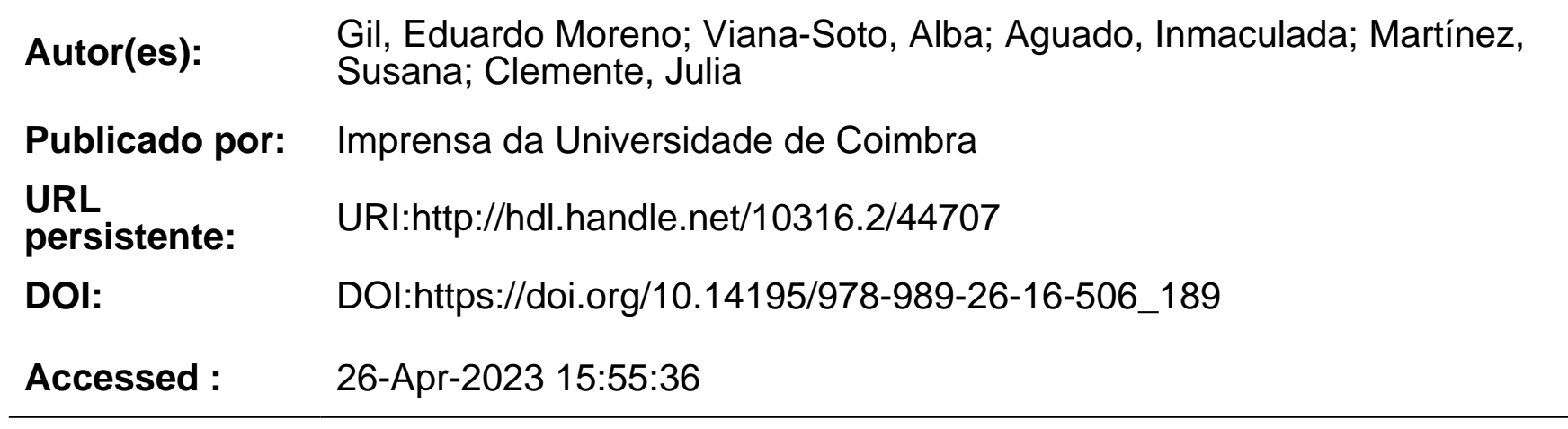

A navegação consulta e descarregamento dos títulos inseridos nas Bibliotecas Digitais UC Digitalis, UC Pombalina e UC Impactum, pressupõem a aceitação plena e sem reservas dos Termos e Condições de Uso destas Bibliotecas Digitais, disponíveis em https://digitalis.uc.pt/pt-pt/termos.

Conforme exposto nos referidos Termos e Condições de Uso, o descarregamento de títulos de acesso restrito requer uma licença válida de autorização devendo o utilizador aceder ao(s) documento(s) a partir de um endereço de IP da instituição detentora da supramencionada licença.

Ao utilizador é apenas permitido o descarregamento para uso pessoal, pelo que o emprego do(s) título(s) descarregado(s) para outro fim, designadamente comercial, carece de autorização do respetivo autor ou editor da obra.

Na medida em que todas as obras da UC Digitalis se encontram protegidas pelo Código do Direito de Autor e Direitos Conexos e demais legislação aplicável, toda a cópia, parcial ou total, deste documento, nos casos em que é legalmente admitida, deverá conter ou fazer-se acompanhar por este aviso.

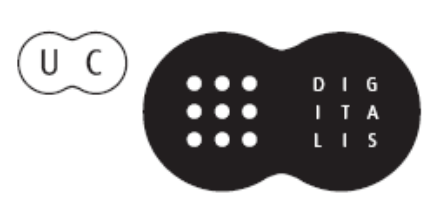




\section{ADVANCES IN}

\section{FOREST FIRE RESEARCH}

\section{8}

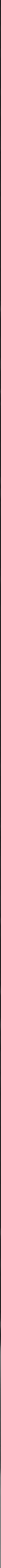


Short contribution - Decision Support Systems and Tools

RPI Engine: Visualization in a web environment of post-fire regeneration using Landsat time series

\author{
Eduardo Moreno Gil ${ }^{1}$; Alba Viana-Soto*1; Inmaculada Aguado ${ }^{1}$; Susana Martínez ${ }^{2}$; Julia Clemente ${ }^{3}$ \\ ${ }^{1}$ Department of Geology, Geography and Environment, University of Alcala, Calle Colegios, 2, 28801 \\ Alcalá de Henares, Spain; \{eduardomorenogil@gmail.com,albal3vs@gmail.com*, \\ inmaculada.aguado@uah.es\} \\ ${ }^{2} 3 e d a t a$ Ingeniería Ambiental. Complejo El Palomar, Palacio de Ferias y Congresos, s/n-27004 Lugo, \\ Spain; \{campoxurado@gmail.com\} \\ ${ }^{3}$ Department of Automatic, University of Alcala, University Campus, Alcalá de Henares, Spain; \\ \{julia.clemente@uah.es\}
}

\begin{abstract}
The main objective of this study is to develop a web visualization tool which allows recognizing post-fire vegetation regeneration at pixel level from selected burned areas. Regeneration trajectories are based on the variations that spectral indices have (NDVI, NBR and TCW). Making use of the Earth Engine Code Editor platform (EECE) has been possible through the use of JavaScript language and other algorithms already integrated in Google Earth Engine (GEE), to generate those indices from Landsat time series (1984-present). Moreover, we implemented the graphical interface with which the user can visualize and interact with results and additional information.
\end{abstract}

Keywords: post-fire regeneration, Large Forest Fires, remote sensing, Google Earth Engine, Landsat time series, temporal trajectories.

\title{
1. Introduction
}

Wildfires are one of the most important environmental problems at present. In the European context, Spain is among the countries with the highest fire incidence in number and burned surface (SanMiguel-Ayanz et al. 2017). The analysis of Large Forest Fires (LFF, according to the statistics in Spain, $>500$ hectares) has special interest despite its low frequency as they are the ones that cause the greatest environmental and social damage. In the 90s in Spain, the year 1994 was the second worst in the statistical time series regarding the area affected by fire, with a total of 437,602 burned hectares. From these, almost $80 \%$ of were burned in $93 \mathrm{LFF}$.

Over the last few years several studies have underlined the importance of remote sensing to analyse ecological dynamics following fire and study post-fire vegetation regeneration (Lentile et al. 2006, Bartels et al. 2016). Satellite images provide broader information of burned areas by obtaining biophysical variables of wildfires. Due to the open data availability, new advances and challenges have arisen in remote sensing applied to fires (Gitas et al. 2014). Large time series of Landsat have been widely used to assess post-fire vegetation regeneration (Röder et al. 2008, Pickell et al. 2016, Chu et al. 2017, Martínez et al. 2017). At present the GEE cloud processing platform is available for open use. This tool enables us to study regeneration dynamics by using large time series and auxiliary data optimizing processing time, and also provides a visualization of results in a web environment (Gorelick et al. 2017).

This research is part of the Spanish scientific project SERGISAT, which main objective is to study the vegetation recovery dynamics from a selection of LFF that occurred in 1994 in the Spanish Mediterranean biogeographic region. In this context, this research aims to develop a tool which allows 
analysing regeneration trajectories and disseminating the results through the visualization in a web environment.

\section{Materials and Methods}

This research utilizes the free and open access to imagery available from the Landsat satellite programme and auxiliary data in order to explain the regeneration dynamics (fire perimeters, fire severity and forest cover). Six burned areas with comparable biophysical characteristics were selected as study areas in the SERGISAT project. We present here the case of the Uncastillo fire occurred on July 161994 where 16,442 hectares were burnt (Figure 1).

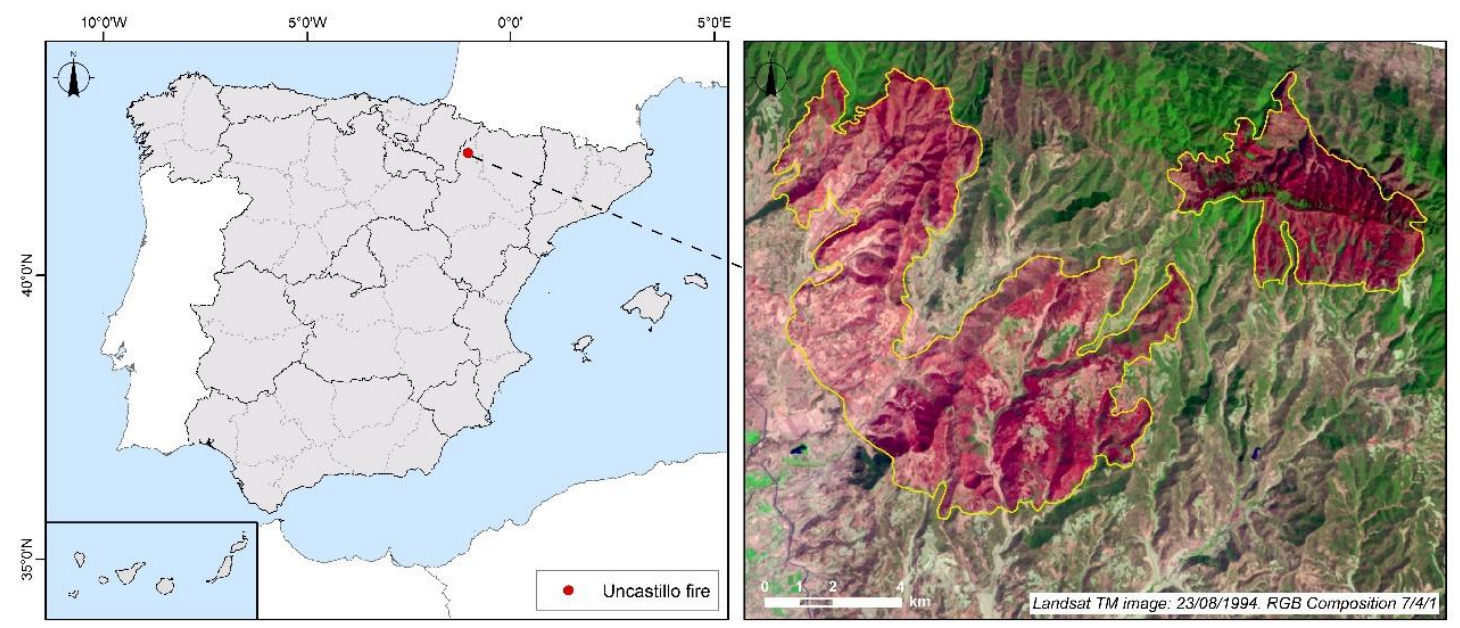

Figure 1 - Location of the study area and false colour image after the Uncastillo fire.

A time series from 1984 to present was generated by using the Landsat collection provided by GEE. We used the Collection Surface Reflectance Tier 1 from Landsat TM, ETM+ and OLI. This dataset is the atmospherically corrected surface reflectance which contains 4 visible and near-infrared (VNIR) bands and 2 short-wave infrared (SWIR) bands processed to orthorectified surface reflectance. These data have been atmospherically corrected using LEDAPS, Landsat Ecosystem Disturbance Adaptive Processing System (Masek et al. 2006) and include a cloud, shadow, water and snow mask produced using CFMASK, C Function of Mask (Foga et al. 2017), as well as a per-pixel saturation mask. A total of five WRS-2 scenes were used selecting images between June and September of each year with less than $1 \%$ cloud coverage. All the Landsat products used have been generated by Google using a "Docker" image provided by the USGS (Gorelick et al. 2017).

Additionally, an annual forest cover map of the year 2016 generated by the Space Observation Center of the Japanese agency (JAXA) is avaliable on GEE, which represent in one band the Forestry and Non Forestry coverage (FNF) for the entire terrestrial globe. Moreover, we used information generated in the SERGISAT project as the fire perimeters obtained by using Burned Area Algorithm Software (BAMS) (Bastarrika et a. 2014), fire severity images measured by GeoCBI (De Santis and Chuvieco 2009), and a vegetation cover map created combining the Corine Land Cover 1990 and the Second National Forest Inventory of Spain (1986 - 1995) to identify the pre-fire vegetation recovery.

The programming was done through JavaScript language using the EECE algorithms to calculate three spectral index: the Normalized Difference Vegetation Index (NDVI) (Rouse et al, 1984), Normalized Burn Ratio (NBR) (Key \& Benson 2003), and Tasseled Cap Transformation-Wetness (TCW) (Crist 1985, Huang et al. 2002, Baig et al. 2014).

In order to detect areas where regeneration is continued over time, we used the algorithm ee.Image Collection.formaTrend integrated in GEE. This algorithm makes a search of trends around a main condition to define thresholds from the indices values. Values within the thresholds represent 
areas were regeneration was continuous. Results are filtered to isolate positive values (continuous trend) and final values are presented in a range between 0 and the maximum for each index. Finally, a graphical interface has been implemented in which the user can visualize and interact with the results, establishing the desired graphic style from the CSS code.

\section{Results and Discussion}

The web tool developed has been called RPI Engine (Post-Fire Engine Regeneration) and is accessible at the following link: https://code.earthengine.google.com/cca8d5a8403c91ff1e06118ccb42c67f

The main screen of RPI Engine (Figure 2) shows the different options with which the user can interact at the beginning of the application. It is organized in three sections: the central one corresponds to the map (result display area), the right part consists of a panel in which different burned areas can be selected, spectral indices can be calculated, and auxiliary information can be added. Finally, the left section shows graphics that represent spectral trajectories.

The algorithm implemented has allowed to extract continuous regeneration trends that have occurred in each fire. Figure 2 shows the results obtained for the Uncastillo fire. The user could evaluate the regeneration trends comparing visually the actual vegetation cover with the forest map of 2016 created by JAXA. In this context, in spite of its ecological interest we have not considered areas with a discontinuous trajectory, because this was not considered in the SERGISAT project. That is why there are gaps within the burned area perimeter.

Compared to other viewers, the RPI Engine has fewer functions to interact with, being a viewer exclusively designed to extract trajectories of the programmed indices. Other similar examples as Climate Engine viewer (http://climateengine.org/, last accessed on 27 June 2018, Huntington et al. 2017) have more capacity allowing the user to generate statistics of pixel data from numerous layers of climate information, or GFW (https://www.globalforestwatch.org/, last accessed on 27 June 2018), designed to see changes in forest cover and offers the possibility of reproducing the images. It is our intention to continue our line of work to include in the RPI Engine some of the capabilities of these viewers.

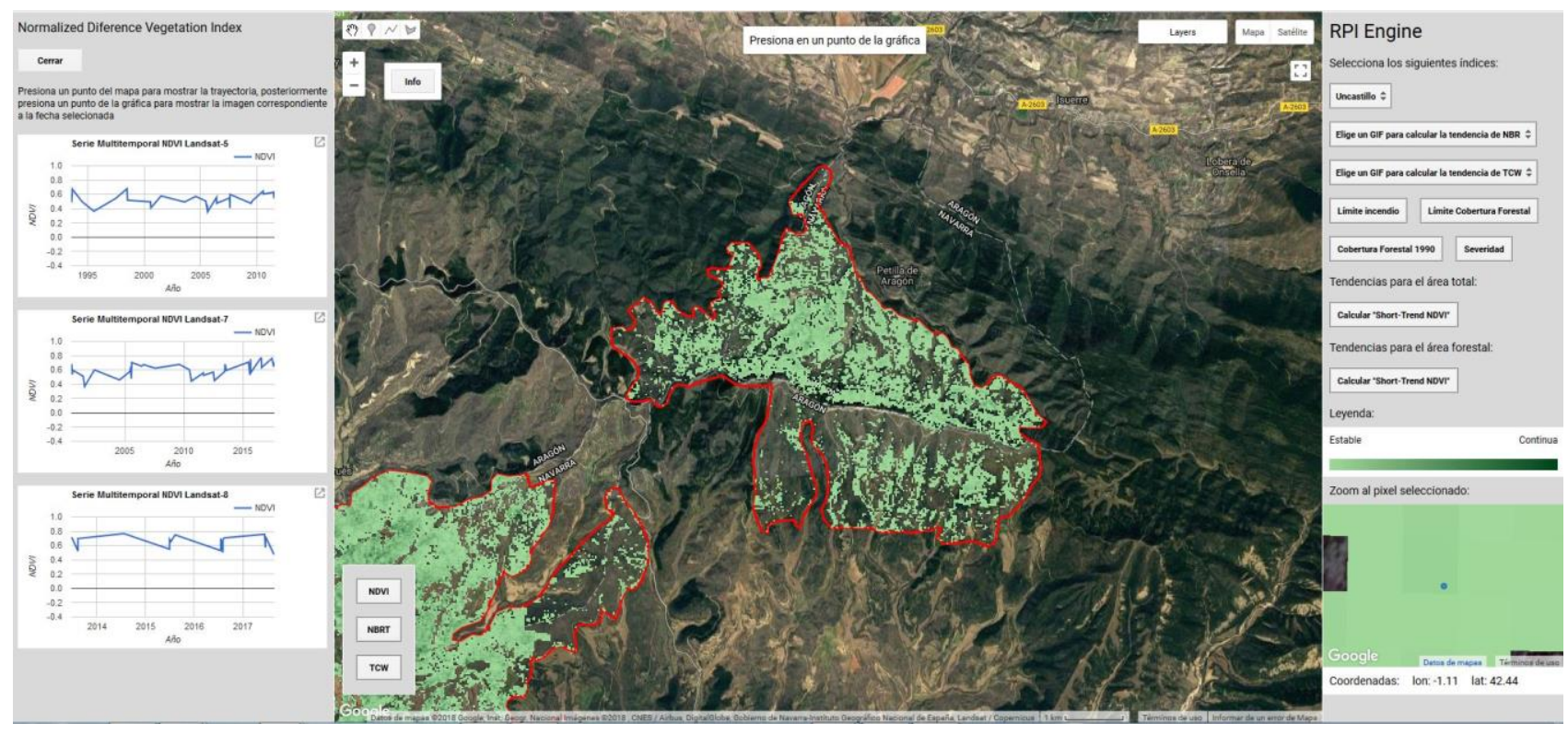

Figure 2 - RPI Engine user interface. Areas with continuous regeneration trends, using NDVI and Spectral trajectories for each Landsat Collection. 


\section{Conclusion}

The GEE platform has provided a framework to evaluate forest fires regeneration from a large amount of satellite data available. In this study we have taken advantage of this platform to exploit a long time series of Landsat satellite data.

Advances in this research could help decision-makers in determining which forest areas would have difficult regenerating processes after LFF, thus requiring the implementation of specific restoration programmes. In addition, web visualization will provide users with information and other spatial analysis functions necessary for studies in similar areas.

\section{Acknowledgements}

This study was supported by the Project "Severity and Regeneration after large forest fires from satellite remote sensing and geographic information systems" (SERGISAT; http://www.sergisat.es/), funded by the Ministry of Economy, Industry and Competitiveness of Spain.

\section{References}

Baig MHA, Zhang L, Shuai T, Tong Q (2014) Derivation of a Tasselled Cap Transformation Based on Landsat 8 at-Satellite Reflectance. Remote Sensing Letters 5 (5), 423-431.

Bartels SF, Chen HYH, Wulder MA, White JC (2016) Trends in post-disturbance recovery rates of Canada's forests following wildfire and harvest. Forest Ecology Management 361, 194-207.

Bastarrika A, Alvarado M, Artano K, Martinez M, Mesanza A, Torre L, et al. (2014) BAMS: A tool for supervised burned area mapping using Landsat data. Remote Sensing 6, 12360-12380

Chu T, Guo, X, Takeda K (2017) Effects of burn severity and environmental conditions on post-fire regeneration in Siberian Larch forest. Forests, 8, 76.

Crist EP (1985) A TM Tasseled Cap Equivalent Transformation for Reflectance Factor Data. Remote Sensing of Environment 17 (3), 301-306.

De Santis A, Chuvieco E (2009) GeoCBI: A modified version of the Composite Burn Index for the initial assessment of the short-term burn severity from remotely sensed data. Remote Sensing of Environment 113, 554-562.

Foga S, Scaramuzza PL, Guo S, Zhu Z, Dilley RD, Jr Beckmann T, Schmidt GL, Dwyer, JL, Joseph Hughes M, Laue B (2017) Cloud Detection Algorithm Comparison and Validation for Operational Landsat Data Products. Remote Sensing of Environment 194, 379-390.

Gitas IZ, San-Miguel-Ayanz, J, Chuvieco E, Camia, A (2014) Advances in remote sensing and GIS applications in support of forest fire management. International Journal of Wildland Fire 23(5), 603-605.

Gorelick N, Hancher M, Dixon, M, Ilyushchenko S, Thau, D, Moore R (2017). Google Earth Engine: Planetary-scale geospatial analysis for everyone. Remote Sensing of Environment 202, 18-27.

Huang C, Wylie B, Yang L, Homer C, Zylstra G (2002) Derivation of a Tasselled Cap Transformation Based on Landsat 7 at-Satellite Reflectance». International Journal of Remote Sensing 23 (8), 1741-1748.

Huntington JL, Hegewisch KC, Daudert B, Morton CG, Abatzoglou JT, McEvoy DJ, Erickson T (2017) Climate Engine: Cloud Computing and Visualization of Climate and Remote Sensing Data for Advanced Natural Resource Monitoring and Process Understanding. Bulletin of the American Meteorological Society 98 (11), 2397-2410.

Key CH, Benson NC (1999) The Normalized Burn Ratio (NBR): A Landsat TM radiometric measure of burn severity. United States Geological Survey, Northern Rocky Mountain Science Center. (Bozeman, MT).

Lentile LB, Holden ZA, Smith AMS, Falkowski MJ, Hudak AT, Morgan P, Lewis SA, Gessler PE, Benson NC (2006) Remote sensing techniques to assess active fire characteristics and post-fire effects. International Journal of Wildland Fire 15, 319-345. 
Martínez S, Chuvieco E, Aguado, I, Salas J (2017). Burn severity and regeneration in large forest fires: an analysis from Landsat time series. Revista de Teledetección 49, 17-32.

Masek JG, Vermote EF, Saleous NE, Wolfe R, Hall FG, Huemmrich KF et al. (2006). A Landsat surface reflectance dataset for North America, 1990-2000. IEEE Geoscience and Remote Sensing Letters 3(1), 68-72.

Pickell PD, Hermosilla T, Frazier RJ, Coops NC, Wulder MA (2016) Forest recovery trends derived from Landsat time series for North American boreal forests. International Journal of Remote Sensing 37, 138-149.

Röder A, Hill J, Duguy B, Alloza JA, Vallejo R (2008) Using long time series of Landsat data to monitor fire events and post-fire dynamics and identify driving factors. A case study in the Ayora region (eastern Spain). Remote Sensing of Environment 112, 259-273.

San-Miguel-Ayanz S, Durrant T, Boca R, Libertà G, Branco A, de Rigo D, Ferrari D, Maianti P, Vivancos TA, Schulte E, Loffler P (2017) Forest Fires in Europe, Middle East and North Africa 2016. (Publications Office of the European Union: Luxembourg) DOI: 10.2760/17690. 